\section{Catalytic Stereoselective Synthesis of Pronucleotides}

pronucleotides

P-based stereogenic centers

nucleosides

medicinal chemistry<smiles>CC(NP(=O)(Cl)Oc1ccccc1)C(=O)OCc1ccccc1</smiles>

1 (mixture of diastereomers)<smiles>CC1(Cl)C(n2ccc(=O)[nH]c2=O)O[C@H](CO)[C@H]1O</smiles>

catalyst (mol\%) none

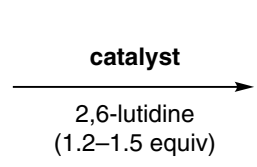

(1.2-1.5 equiv)<smiles>CCOC(=O)C(C)C</smiles><smiles>COP(N)(=O)Oc1ccccc1</smiles><smiles>CC1OC(n2ccc(=O)[nH]c2=O)C(C)C1C</smiles>

pronucleotide (MK-3682)

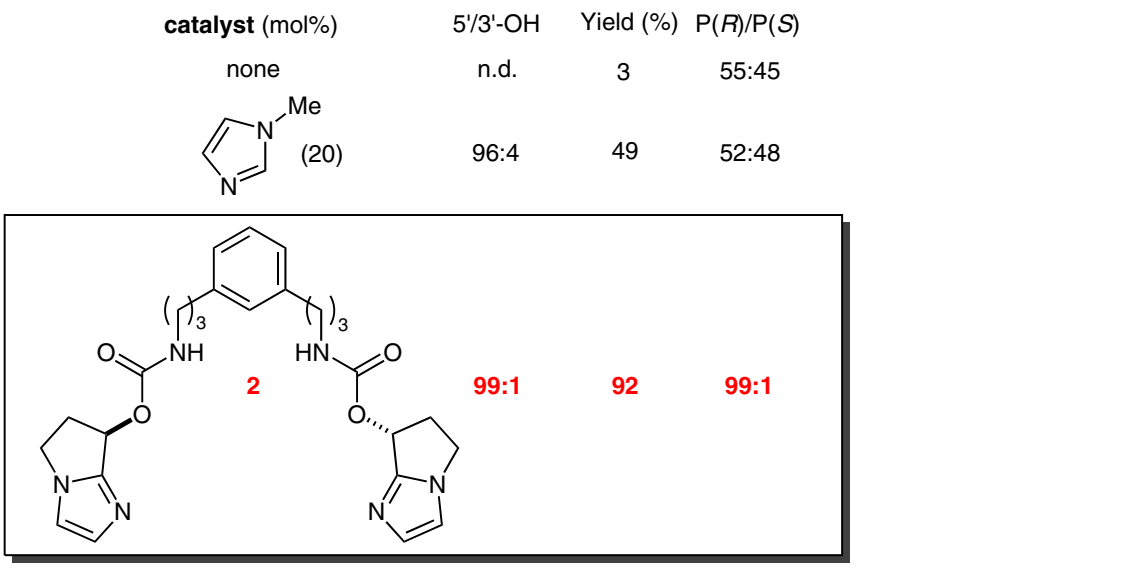

Selected further nucleoside substrates:

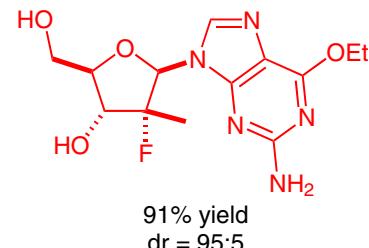

$\mathrm{dr}=95: 5$

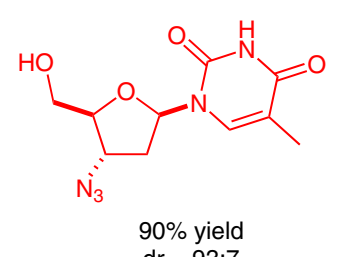

$\mathrm{dr}=93: 7$

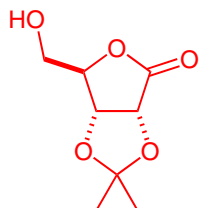

$95 \%$ yield

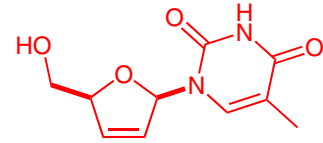

$96 \%$ yield $\mathrm{dr}=87: 13$

[\% NMR yields and diastereomeric ratios (dr) of 5'-O-phosphorylated products]

Significance: DiRocco and co-workers report a diastereoselective synthesis of pronucleotides from the corresponding nucleosides by a dynamic kinetic resolution of chlorophosphoramidate $\mathbf{1}$ Whereas the reaction with $N$-methylimidazole as catalyst proceeds with almost no stereoselectivity toward the newly formed stereogenic center on phosphorus, a dimeric, chiral, imidazole-based catalyst with additional hydrogen-bonding sites furnished a series of pronucleotides in good yields and good to excellent stereoselectivities.

SYNFACTS Contributors: Benjamin List, Lucas Schreyer Synfacts 2017, 13(08), 0867 Published online: 18.07.2017 DOI: $10.1055 / \mathrm{s}-0036-1590687$; Reg-No.: B05317SF
Comment: Pronucleotides are important compounds for the treatment of viral diseases and cancer. The derivative MK-3682, for instance, is a hepatitis C viral RNA polymerase inhibitor, currently undergoing late-stage clinical trials. Because different absolute configurations of the P-based stereogenic center can significantly alter the drug's potency and toxicity, stereoselective generation thereof is of great importance. Herein, the authors report the first catalytic, stereoselective access to compounds bearing P-based stereogenic centers. 